\title{
Membrane Technology and Water Reuse in a Dairy Industry
}

\author{
Douglas Felipe Galvão
}

Additional information is available at the end of the chapter

http://dx.doi.org/10.5772/intechopen.76464

\begin{abstract}
The dairy industry uses substantial amount of water to achieve the production process, especially for the maintenance of hygiene and cleanliness conditions. With this, is generating considerable volume of wastewater requiring treatment to meet the discharge standards before discarded? With the shortage of water resources and charging for water use, minimizing water consumption in industries is of paramount importance to maintain its market competitiveness. In this sense, there has been increasing interest in the reuse of wastewater, in order to decrease the good water consumption by processes that do not require such high quality feature. Membrane separation processes are highlighted in generating good-quality reuse water that can meet the demand of various industrial processes. Thus, the present study aimed to evaluate the membrane separation processes for the treatment of dairy industry effluent to reuse.
\end{abstract}

Keywords: milk, membrane, water, reuse, technology

\section{Introduction}

The dairy industry is responsible for the consumption of high volume of water, being the natural resource most used in the productive process of the sector. The need for water mainly occurs to maintain the conditions of cleaning, sanitary, and hygiene within the production sectors. With the high consumption of water, the generation of considerable effluent flow occurs, which makes the dairy industry a potential polluter. The effluents of the dairy industry contain organic matter, whey, and other constituents of milk, cleaning products, and soaps.

It is necessary to treat this effluent in order to meet the release standards set forth in the legislation and, consequently, reduce the pollutant loads released into the water environment. In 
this sense, it becomes important the study for the proposal of methods of treatment of effluents and water reuse in the dairy industry. The possibilities of reuse of the effluent after treatment for industrial processes are restricted to the dairy industry, depending on the country and the legislation applied to the segment, since it is a food production industry. However, even in these industries, there is the possibility of reuse for cleaning floors, garden watering, cooling water, and use water in boilers.

Membrane separation processes have been prominent in recent years regarding the treatment of effluents for their reuse, since it allows the use of compact treatment systems, generating good-quality reuse water, which makes it possible for industries to save. In membrane separation systems, synthetic membranes are used, which imitate the selectivity characteristics of natural membranes, in order to separate, concentrate, or purify the substances present in the water, making it of better quality. A hydraulic pressure gradient or electric field must be applied in order for the separation to occur [1]. In this way, membrane separation processes have generated interest in the dairy industry, especially for the possibility of generating goodquality reuse water that can help to minimize consumption, as well as reduce the generation of effluents by these industries.

With the objective of elucidating membrane separation processes in the treatment of dairy effluents, research was carried out in the national and international literature, using previously published studies on the subject, verifying results obtained and the importance with regard to the reuse of water and the valorization of products.

\section{Water in the dairy industry}

In industry, water has several types of use; the main ones are presented below [2]:

A. human consumption: Water used in sanitary environments, changing rooms, kitchens and dining rooms, drinking fountains, safety equipment, or any domestic activity with direct human contact

B. raw material: As raw material, water will be incorporated into the final product, as is the case in the beer and soft drinks industries, or water is used to obtain other products, for example, hydrogen by electrolysis of water

C. use as an auxiliary fluid: Water, as auxiliary fluid, stands out for the preparation of chemical suspensions and solutions, intermediate compounds, chemical reagents, and vehicle or for washing operations

D. use for energy generation: Transformation of kinetic, potential, or thermal energy, accumulated in water, in mechanical and electrical energy

E. use as heating and/or cooling fluid: In these cases water is used as heat transfer fluid to remove heat from reactive mixtures or other devices that require cooling

F. other uses: The use of water for firefighting, irrigation of green areas, or incorporation in various byproducts generated in industrial processes, whether in the solid, liquid, or gas phase 
In the dairy industry, water consumption is significant, being the natural resource most used in this sector [3]. The authors, Saraiva et al. [4, 5], investigating the consumption of water in the dairy industry found the coefficients shown in Table 1, which refer to the types of products produced.

The consumption of water is quite variable, related to the size of the dairy, the standardization of activities, reuse practices, the technologies employed, and the type of product produced. The mean intakes reported for different European and Nordic countries are shown in Table 2.

The high consumption of water in the dairy industry is related to the need to maintain sanitary and hygiene conditions and is mainly due to cleaning operations, milk washing, cooling, and steam generation [3]. According to Vourch et al. [6], the water consumption of the dairy industries will depend on the volume of milk that is processed, the water quality required for the different industrial processes, and the water management practices in the industry.

By analyzing the data presented in Tables $\mathbf{1}$ and 2, it is possible to notice that the highest coefficient of consumption found by Saraiva et al. [4] occurs in the production of yogurt, presenting a consumption of 10 liters of water for each liter of processed milk. This figure was above the other production lines and was well above the figures cited by Maganha [3] for European and Nordic countries. Differently from Saraiva et al. $[4,5]$ found high consumption for the production of milk candy, but they mentioned the possibility of standardization of processes, reduction of waste by dairy employees, and adoption of reuse practices as ways of reducing consumption of this production line. Looking at the data, it can be observed that consumption can vary widely according to the production lines, as well as the water management practices of the dairy industries, which makes relevant the development of studies referring to better forms of use and reuse of water.

\subsection{Liquid effluents from the dairy industry}

Industrial effluents are liquid streams from processes, operations, and utilities in industries [7]. It is also possible to consider the currents originated from the processes and operations in which water is used, but there is no incorporation of this in the final product, besides the net

\begin{tabular}{llc}
\hline Activity/product & \multicolumn{2}{l}{ Water/consumption $\left(\mathbf{L ~ L}^{-1}\right.$ of processed milk) } \\
\cline { 2 - 3 } & $\mathbf{( 1 )}$ & $\mathbf{( 2 )}$ \\
\hline Yogurt & 10 & 5.15 \\
Butter & 1 & - \\
Mozzarella cheese & 1.55 & - \\
Ricotta cheese & 0.2 & - \\
Curd & 1.4 & - \\
Creamy cheese & 1.39 & 9.14 \\
Milk candy & - & \\
\hline
\end{tabular}

Source: (1) adapted from [4] and (2) adapted [5].

Table 1. Water consumption in the dairy industry in different production lines. 


\begin{tabular}{lllll}
\hline Product & \multicolumn{4}{l}{ Water consumption (L L of processed milk) $^{-1}$} \\
\cline { 2 - 5 } & Sweden & Denmark & Finland & Norway \\
\hline Milk and yogurt & $0.96-2.8$ & $0.6-0.97$ & $1.2-2.9$ & 4.1 \\
Cheese & $2.0-2.5$ & $1.2-1.7$ & $2.0-3.1$ & $2.5-3.8$ \\
Powdered milk and/or liquid products & $1.7-4.0$ & $0.69-1.9$ & $1.4-4.6$ & $4.6-6.3$ \\
\hline
\end{tabular}

Source: adapted from [3].

Table 2. Water consumption in dairy products from different Nordic and European countries.

part from the raw material that is removed in the industrial processes [8]. Industrial effluents vary according to the technologies that are used in the production processes, the values of raw materials and inputs, the age of the industry, and the specialization of the equipment operators, besides the way of operation if it is continuous or intermittent [1].

The characteristics of the effluents can be biodegradable, similar to sanitary sewage, or completely nonbiodegradable, especially those from industries of metallic products such as electroplating. The food, paper, and cellulose and sugar-alcohol industries are characterized by the generation of biodegradable effluents rich in organic matter [8].

In the case of food industries, the dairy industry is characterized by high water consumption and, consequently, high effluent production. Table 3 lists the volumes of effluents generated in the dairy industry, according to the type of product produced.

For Tchamango et al. [9], dairy products are characterized by the high generation of liquid effluents, with high oxygen demand (COD) due to their high organic load. In many cases the generated effluent ends up being released directly into the rivers, contributing to its eutrophication by the phosphorus and nitrogen components present in the effluent. The characteristics of the generated effluents vary widely according to the standard and technologies used in the dairy industry. In general, they present high concentrations of organic matter and considerable amounts of nutrients, suspended solids, organic pollutants, and infective agents, as well as milk residues, proteins, carbohydrates, fats, and residues of cleaning agents $[4,10]$.

In addition, Table 4 shows the characteristics for the different parameters of the raw dairy effluent, according to Maganha [3].

\begin{tabular}{ll}
\hline Product type & $\begin{array}{l}\text { Volume of liquid effluents }\left(\mathrm{L}^{-1} \mathbf{~ o f ~}\right. \\
\text { processed milk) }\end{array}$ \\
\hline "White" products (milk, cream, and yogurt) & 3 \\
$\begin{array}{l}\text { "Yellow" products (butter and cheese) } \\
\begin{array}{l}\text { "Special" products (concentrated of milk or whey and dehydrated milk } \\
\text { products) }\end{array}\end{array}$ & 5 \\
\hline
\end{tabular}

Source: [3].

Table 3. Effluent volume generated per kilogram of milk processed in the different production lines of the dairy industry. 


\begin{tabular}{|c|c|c|}
\hline \multirow[t]{2}{*}{ Parameter } & \multicolumn{2}{|c|}{ Variation range } \\
\hline & (1) & (2) \\
\hline Suspended solids $\left(\mathrm{mg} \mathrm{L}^{-1}\right)$ & $24-5700$ & $100-1000$ \\
\hline Total suspended solids $\left(\mathrm{mg} \mathrm{L}^{-1}\right)$ & $135-8500$ & 100-2000 \\
\hline $\operatorname{COD}\left(\mathrm{mg} \mathrm{L}^{-1}\right)$ & $500-4500$ & 6000 \\
\hline $\mathrm{BOD}\left(\mathrm{mg} \mathrm{L}^{-1}\right)$ & $450-4790$ & 4000 \\
\hline Protein $\left(\mathrm{mg} \mathrm{L}^{-1}\right)$ & $210-560$ & Undefined \\
\hline Grease/oils and greases $\left(\mathrm{mg} \mathrm{L}^{-1}\right)$ & $35-500$ & $95-550$ \\
\hline Carbohydrate $\left(\mathrm{mg} \mathrm{L}^{-1}\right)$ & $252-931$ & Undefined \\
\hline Ammonia $\left(\mathrm{mg} \mathrm{L}^{-1}\right)$ & $10-100$ & Undefined \\
\hline Nitrogen $\left(\mathrm{mg} \mathrm{L}^{-1}\right)$ & $15-180$ & 116 \\
\hline Phosphor (mg L ${ }^{-1}$ ) & $20-250$ & $0.1-46$ \\
\hline Sodium $\left(\mathrm{mg} \mathrm{L}^{-1}\right)$ & $60-807$ & Undefined \\
\hline Chlorides $\left(\mathrm{mg} \mathrm{L}^{-1}\right)$ & $48-469$ & Undefined \\
\hline Calcium (mg L $\left.{ }^{-1}\right)$ & $57-112$ & Undefined \\
\hline Magnesium (mg L-1) & $22-49$ & Undefined \\
\hline Potassium $\left(\mathrm{mg} \mathrm{L}^{-1}\right)$ & $11-160$ & Undefined \\
\hline $\mathrm{pH}$ & $5.3-9.4$ & $1-12$ \\
\hline Temperature $\left({ }^{\circ} \mathrm{C}\right)$ & $12-40$ & $20-30$ \\
\hline
\end{tabular}

(1) Environment Agency of England and Wales, 2000; European Commission-Integrated Pollution Prevention and Control Jan/2006. (2) Associação Brasileira da Indústria de Queijo (ABIQ).

Table 4. Physical and chemical characterization of effluents from the dairy industry.

The characteristics of the effluents vary considerably between different activities of milk industrialization. Table 5 shows the generation of BOD in the effluent related to the population equivalent, which can demonstrate the high organic load released in the dairy effluent.

These wastewaters, if disposed of in water resources without adequate treatment, may cause a number of problems, such as the mortality of aquatic species, damage to public health through the consumption of contaminated water, and an increase in the costs of treatment of this resource [12].

Thus, it is important to use optimized effluent treatment systems that are integrated with the identification of the liquid waste generation points in the production process, so that sustainable production can be achieved [4].

\subsection{Water reuse in industry}

The use of water combined with its high consumption in industry has led this segment to seek internal reuse alternatives and to consider the purchase of treated effluents from sanitation companies at prices lower than those of drinking water [13]. In this sense, Hespanhol [14] 


\begin{tabular}{|c|c|c|c|}
\hline Industrial unit & $\begin{array}{l}(\mathrm{DBO}) \\
\left(\mathrm{mg} \mathrm{L}^{-1}\right)\end{array}$ & $\begin{array}{l}\text { Specific load of BOD }(\mathrm{kg} \\
\text { BOD } / \mathrm{m}^{3} \text { of processed milk) }\end{array}$ & $\begin{array}{l}\text { Population equivalent (equivalent } \\
\text { inhab/L } / \mathrm{L}^{-1} \text { of processed milk) }\end{array}$ \\
\hline $\begin{array}{l}\text { Milk reception and cooling } \\
\text { station }\end{array}$ & $600-1200$ & 1.2 & 24 \\
\hline Milk and butter packaging & $800-1600$ & 3.0 & 60 \\
\hline Cheese factory & $3000-6000$ & 18.0 & 368 \\
\hline Yogurt & $1500-3500$ & 5.0 & 100 \\
\hline Milk drying tower & $600-1200$ & 1.3 & 27 \\
\hline
\end{tabular}

Source: [11].

Table 5. Comparison between the BOD generated in a dairy and population equivalent of the generated organic load.

states that one should choose to satisfy those demands that require water of not very high quality by less noble sources and use of sources of superior quality only for nobler uses, such as domestic supply. In response to such conditions, the development of effluent treatment technologies has increased in order to meet the quality limits for reuse. Thus, reuse waters can become an important contribution to the water supply in the industry [6, 15-17].

It is possible to define reuse as the use of the effluent directly or after some treatment steps in other processes, according to the water quality required. Not all of the effluent generated needs to be treated for reuse, but in some cases, there is a need for specific purification treatments [18]. Reuse can also be conceived as the use of treated or untreated effluents for purposes that are beneficial, such as irrigation, industrial use, and urban purposes that are not potable [1]. Mierzwa [19] asserts, however, that the practice of reuse should not be seen as the goal of any model of water resource management in an industry, not meeting the requirements of Agenda 21, which exposes the rational use of water as a goal main.

Some industrial processes, more specifically those of the food industry, do not allow the use of reuse water in their production processes. However, even in these industries, there is the possibility of reusing water in processes that demand less noble water quality, such as for cooling, boiler feed, floor cleaning, and sanitary discharges in toilets, among others.

Due to the existing treatment techniques in the industries, a treated effluent can present similar, or even better, physical, chemical, or biological characteristics than the raw water. In the same way, effluents from certain processes present adequate quality to other processes, without the need for treatment [1].

In this sense, industrial water reuse can be classified into two broad forms of application, namely, external macro reuse, which refers to the use of treated effluents from stations administered by utilities or other industries, and the internal macro reuse, referring to the internal use of effluents, treated or not, from activities carried out in the industry itself [20].

One form of reuse that has gained relevance is cascading reuse. This form of reuse is a type of internal macro use, in which the industrial effluent originated in a certain process is directly used in a subsequent process [2]. It is important to emphasize the need to verify if the water 
quality of the effluent is adequate for the next process. This type of reuse is the most interesting for the industries, because, just as the amount of water used will decrease, the amount of effluent generated also decreases. However, the concentration of specific pollutants and pollutants increases with this type of reuse [1]. In addition, cascade reuse does not require treatment of the effluent, since it is in the appropriate quality to be reused in another process that does not require a high quality, which ends up decreasing the amount spent for the reuse of water.

\subsubsection{Reuse of treated effluents}

It is the form of reuse that has been most applied in industry and is characterized by the use of the effluents generated in the site in other industrial processes, after adequate treatment to reach the required quality to the usage patterns that were preestablished (FIRJAN, 2006).

According to the water quality required in the process and the specific reuse scope, the effluent treatment levels will be established, in which safety criteria will be adopted, as well as related capital, operating, and maintenance costs [14]. Due to the techniques that are used in the treatment of effluents in the industries, the treated effluent sometimes has better characteristics than the raw water or may have aspects suitable for its use in certain processes [1].

The reuse of effluents after treatment can be done directly and after complementary treatment techniques. Direct reuse is accomplished by routing the treatment plant effluent to the site where it will be used. If there is still a contaminant in this effluent that needs to be eliminated to meet the required quality indices, complementary techniques must be adopted for the treatment and subsequent reuse [1].

It is also worth mentioning three categories of reuse water for industry that offer great possibilities of reuse: reuse water in cooling towers and lakes, open cycle (cooling) systems and process, and boiler feed [13].

\subsection{Membrane separation process}

Membrane separation processes use synthetic membranes to separate substances and solids that have small diameters, as well as molecules and ionic compounds, through the application of some type of external force. The external forces used in membrane filtration may be pressure, suction, or even electric potential [21,22]. After the passage of the liquid through the membrane, this happens to be called permeate; what is retained is called concentrated or retentate [23]. Figure 1, below, shows the simplified inlet and outlet diagram of the solution in the membrane.

Mainly because of the charge for water use and the need to preserve the environment, interest in water reuse has gained relevance. In this sense, membrane separation processes in the treatment of effluents are presented as one of the most promising technologies, enabling the reuse of water and, consequently, reducing the consumption of good-quality water in processes that do not demand such high quality, optimizing its use in industrial processes [16]. According to Mierzwa and Hespanhol [1], membrane separation processes differ from conventional filtration systems because the feed flow is parallel to the membranes. These processes have numerous advantages in that membranes are efficient in retaining small-sized solid particles 


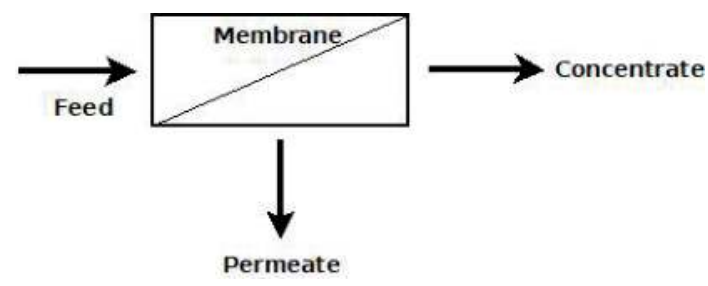

Figure 1. Scheme representing the inlet of the liquid, the outlet of the permeate, and the concentrate (retentate). Source: Adapted from Mierzwa [23].

and dissolved organic and inorganic compounds. In addition, the pressure of the membrane separation system is higher than in conventional filtration processes [1].

The materials used in the production of membranes vary. There are membranes prepared with polymeric materials-organic-and those that are produced with inorganic materials. Inorganic materials have been used in the production of membranes for more than 20 years. However, they have gained more space in the market only recently [22]. The organic materials for the production of the membranes are basically the polymers, and the inorganics are the metals and the ceramics. The most commonly used polymers in the manufacture of membranes are set out below in Table 6 .

The processes using membranes are basically five: microfiltration (MF), ultrafiltration (UF), nanofiltration (NF), reverse osmosis (RO), and electrodialysis (ED) [21]. The difference of each is the size of the particles and molecules that are retained and with what intensity the driving force promotes the separation, as visualized in Figure 2 and in Table 7, respectively [7, 22, 24].

\begin{tabular}{ll}
\hline Membrane & Material \\
\hline Microfiltration (MF) & Ceramics \\
& Polypropylene (PP) \\
Ultrafiltration (UF) & Ceramics \\
& Cellulose acetate (CA) \\
& Polysulfone (PS) \\
& Polyethersulfone (PES) \\
& Polyvinylpyrrolidone \\
& Polyacrylonitrile (PAN) \\
Polyvinylidene fluoride (PVDF) & Polyacrylamide \\
Nanofiltration (NF) & Polyamide \\
& Polyacrylamide \\
\hline
\end{tabular}

Source: $[7,24]$.

Table 6. Types of polymers used in the production of different membranes. 

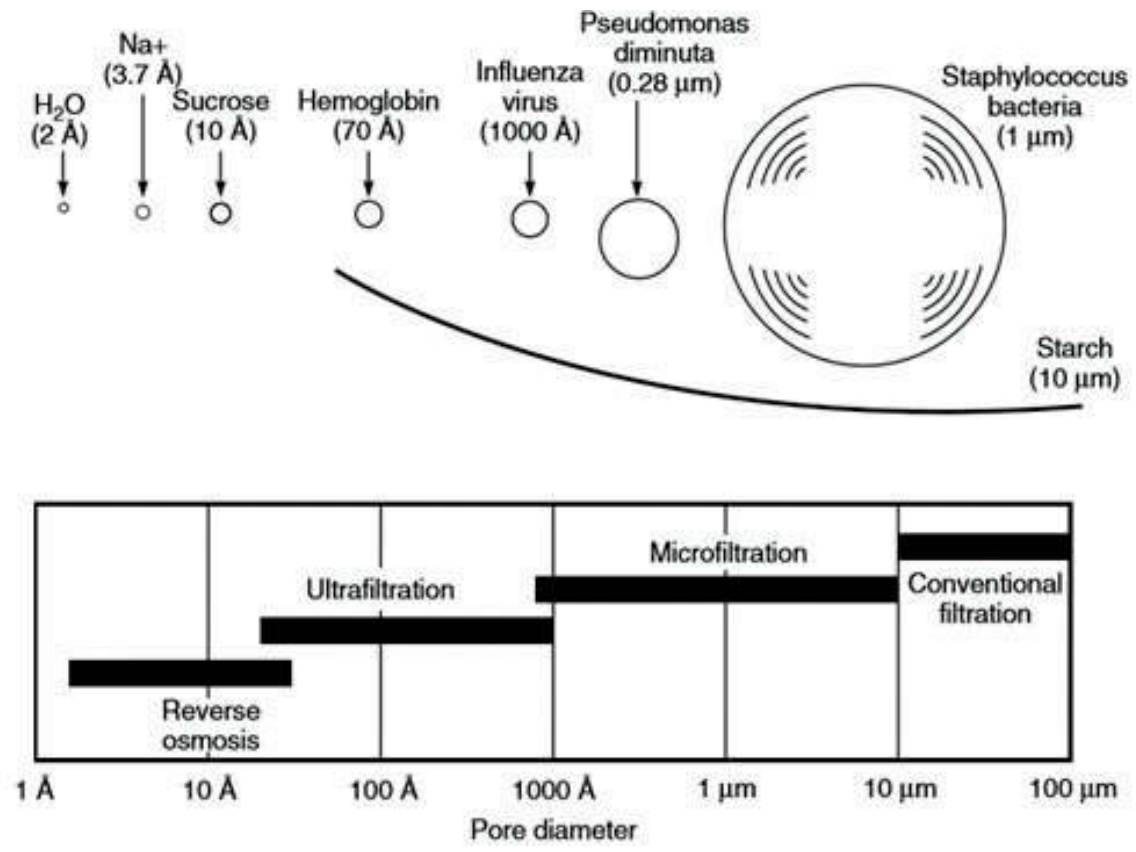

Figure 2. Particles and molecules retained according to the type of membrane separation process. Source: [25].

\begin{tabular}{ll}
\hline Membrane & Driving force \\
\hline Microfiltration (MF) & $<2$ bar \\
Ultrafiltration (UF) & $1-10$ bar \\
Nanofiltration (NF) & $5-35$ bar \\
Reverse osmosis (RO) & Difference of concentration (15-150 bar) \\
Electrodialysis & Voltage and electric current \\
\hline Source: $[7,24]$. & \\
\hline
\end{tabular}

Table 7. Membrane type and driving force.

Compared with traditional physicochemical techniques to membrane treatment systems, a number of advantages can be cited, such as the need for chemical treatment only for membrane cleaning and high transfer rate occurring during the process, while maintaining the purity of the membrane product in ambient conditions [26]. The advantages highlighted are important because they reduce environmental pollution and increase the safety and efficiency of the process.

For the use of the treatment systems by membrane separation processes, it is necessary to use the so-called membrane modules. According to Schneider and Tsutyia [21], the module is a basic system that allows the use of membranes as separation unit. Its composition is 
as follows: membranes, pressure support structures (vacuum or electric current), and feed channels and removal of concentrate and permeate. The main modules are modules with membrane plates, tubular modules, spiral modules, modules with hollow fibers, and modules with rotary disks [21].

\subsubsection{Operation of membrane separation processes and factors influencing flow}

Analyzing a membrane treatment system, Schneider and Tsutyia [21] state that, in addition to the module, these systems are formed by a pressurizing system to pressurize the channel that feeds the membrane, a valve in the concentrate channel that regulates the pressure in the feed channel, a permeate collection channel, and the surface material removal elements.

In membrane separation processes, permeate flow is time independent, depending specifically on the applied pressure potential or the diffusion by the membrane material. This independence of time indicates the mechanical stability of the membrane, the purity of the solvent, and its low interaction with the membrane fabricating material. When there is no observation of one of these conditions, the permeate flux will decrease over time, indicating that there is some change with the membrane [22].

Habert et al. [22] Indicate that the main causes of flux decline the mechanical deformation, the interaction of the solvent with the membrane material, or the presence of impurities in the solvent that causes the clogging of the pore. Schneider and Tsutyia [21] cite that the flow of liquid through the membrane is dependent on some factors, such as pore diameter, porosity of the membrane (fraction of the membrane area occupied by pores), membrane thickness, layer of concentration and polarization, filter cakes (retained material), chemical fouling (precipitated salts or gels), and biofilms.

One of the worst problems cited by the authors during the operation of membrane systems is the decay of the flow over time. This phenomenon is called "fouling" or "membrane fouling" [27-31].

This decrease in flow occurs for two essential reasons: membrane pore blockage, which increases flow resistance, and formation of a fouling layer which creates an additional layer of resistance to permeate flow. Other factors such as adsorption of the solute, deposition of particles within the pores of the membrane, and changes in the characteristics of the fouling layer can affect the fouling of the membrane or increase it or modify both essential fouling phenomena (pore clogging and formation of the scale layer). The formation of the polarization concentration layer may also add a layer of resistance [30].

According to Giacobbo et al. [29], fouling refers to the accumulation of contaminants on the surface or inside the pores of the membrane, causing the decrease of permeate flow. The phenomenon of polarization by concentration is the increase of the solute concentration at the interface membrane/solution, which ends up generating a backscatter of the solute toward the solution. That is, the solute is concentrated in the region close to the membrane/solution interface, preventing the passage of the solvent. According to the authors [27], the reduction in the permeate flux during the filtration, applying constant pressure, occurs due to the deposition of colloidal particles and macromolecules on the surface of the membrane. Thus, the authors state that membrane cleaning should be performed periodically during the operation of the system to prevent the possibility of extreme membrane fouling and even irreversible fouling. 
Fouling eventually increases the complexity of operation of membrane separation systems because the system often needs to be stopped to restore flow through backwashing, resulting in increased cost savings and less use of UF and MF systems for many processes [30].

The ways of cleaning the membranes can be physical and chemical. Physics are dependent on mechanical forces to remove particles accumulated on the surface of the membrane. They include flushing and/or reverse flushing and backwashing [27]. Chemical methods depend on chemical reactions, which break down the forces that bind the adhered substances on the surface of the membrane. Chemical cleaning methods are hydrolysis, digestion, saponification, solubilization, and dispersion [27].

\subsubsection{Membrane separation processes in the treatment of dairy effluents}

Studies using membrane separation processes have varied greatly, mainly because of the great capacity of this process in concentrating, separating, purifying, and treating substances. In the treatment of dairy effluents, some studies will be cited using membranes of microfiltration, ultrafiltration, and nanofiltration, since they are the most used today. It should be noted that such processes are not the only ones but reverse osmosis and dialysis, for example, may also be used in the treatment.

The use of membrane separation processes, in the treatment of industrial effluents, allows high efficiency and the possibility of reuse of effluents in the industry itself. Thus, reuse of wastewater has become an environmentally and economically viable option for industries [16]. Using condensed steam from the dairy industry, Chmiel et al. [32] carried out the nanofiltration in the treatment of this wastewater, being able to maintain all the parameters required for the use as reuse water in the boilers. According to the authors, the reuse of water in the boilers is important for the industries, because in these processes, the volume of water used is considerable. Reuse minimizes waste of water.

In the study of the removal of biochemical oxygen demand (BOD) and chemical oxygen demand (COD) from dairy effluent, Khider et al. [33] used a commercial ultrafiltration membrane and a clay support ultrafiltration membrane. The crude effluent samples were filtered and were able to remove $4000 \mathrm{mg} \mathrm{L}^{-1}$ and $1800 \mathrm{mg} \mathrm{L}^{-1}$ of BOD and COD, respectively, at 90 and $62 \mathrm{mg} \mathrm{L}^{-1}$ with the commercial membrane. For the membrane with clay support, the permeate characteristics reached $60 \mathrm{mg} \mathrm{L}^{-1}$ for BOD and $42 \mathrm{mg} \mathrm{L}^{-1}$ for COD. Since BOD and COD represent the organic load of the effluent, the removal of such parameters is essential for the quality of the effluent to be released.

Baldasso [34] used membranes to separate and fractionate-specific proteins found in whey, discarded material in the treatment of dairy effluents where there is mainly cheese production and which is responsible for great pollution, especially for the large amount of organic matter. Using ultrafiltration membranes, the author found a great possibility for protein fractionation, which is extremely important for the dairy industry.

Luo [35] tested seven ultrafiltration membranes in the treatment of synthetic dairy effluent. UF membranes had cut molecular weight (MWCO) ranging from 5 to $100 \mathrm{kDa}$. For the membranes of $100,30,20$, and 5 ( $\mathrm{kDa}$ ) obtained high efficiency for removal of turbidity, a very relevant result, because the reduced turbidity in effluent has greater acceptance by the population. 
In membrane separation processes, besides the treated effluent being reused as reuse water within the processes, there is the possibility of concentration of the material retained by the membrane and its reuse in the manufacture of new products. This allows the valuation of the resources of the industry. Studies such as Brião and Tavares' [36] that used ultrafiltration as a process of treatment and reuse of dairy effluents found the possibility of reusing the permeate in the cleaning of equipment and the concentrate, after pasteurization, in the production of dairy byproducts such as milk candy.

The use of coagulation associated with membrane separation processes allows high removal of contaminants from the effluents. In this sense, Schimitt et al. [37] used effluent from the process of cleaning pasteurizers from a dairy industry. The UF membrane used was ceramic, with a pore size of $0.1 \mu \mathrm{m}$ and molar retention of $4 \mathrm{kDa}$. They found removals of COD and turbidity above $96 \%$ for treatments using UF associated with Moringa oleifera coagulation.

The authors Kumar et al. [38] fabricated a low-cost ceramic microfiltration membrane and used it in the treatment of dairy effluent. They found that, by increasing permeate flow and pressure, there is a decrease in the removal of chemical oxygen demand. They attributed this fact to the greater pressure and flow force the structure of the membrane, which allows the greater passage of pollutants through it. They achieved a 91\% removal efficiency of COD (135 mg L ${ }^{-1}$ ), which was below the limit allowed for effluent discharge, concluding that the low-cost membrane was successful in treating the effluent.

Galvão [39] studied microfiltration and ultrafiltration membranes in posttreatment of dairy effluent. It found that the efficiency of microfiltration and ultrafiltration membrane separation processes proved to be quite considerable, both in the retention of organic matter and microorganisms and in the removal of nutrients such as nitrogen and phosphorus. As a complementary treatment of dairy effluent, after the treatment by the physical-chemical float, the MF membrane presented a considerable improvement in the effluent quality in both COD and $\mathrm{BOD}_{5}$ retention, as well as in the retention of nutrients such as nitrogen and phosphorus.

\section{Final considerations}

Dairy industries, as potential polluters, need to seek improvements in processes and technologies, to remain competitive and to meet quality requirements in a sustainable way.

Membrane separation processes have been studied and used in the dairy industry, mainly aimed at treating effluents for reuse water generation, which ends up contributing to the preservation of water resources, generates savings for industries, and contributes to sustainability.

The possibilities of study are broadened in the case of membranes, as there is the possibility of reusing the permeate and the concentrate, allowing the reuse of water and materials for the production of byproducts. The studies presented demonstrate the relevance of membrane separation processes and their efficiency in the production of quality reuse water and the possibility of concentrating, separating, and purifying substances. 


\section{Author details}

Douglas Felipe Galvão

Address all correspondence to: fgdoug@gmail.com

Federal Technological University of Paraná, Paraná, Brazil

\section{References}

[1] Mierzwa JC, Hespanhol I. Água na indústria: uso racional e reúso. 1st ed. São Paulo: Oficina de Textos; 2005

[2] Federação Das Indústrias Do Estado De São Paulo - FIESP. Conservação e reúso de Água: Manual de orientações para o setor industrial. 1st ed. São Paulo: CIRRA/IRCWR e DCT Engenharia; 2004

[3] Maganha MFB (Elab.). Guia técnico ambiental da indústria de produtos lácteos-Série P+L. 1st ed. São Paulo: CETESB; 2008

[4] Saraiva CB et al. Consumo de água e geração de efluentes em uma indústria de laticínios. Revista Inst. Latic. "Cândido Tostes". 2009;367/368:10-18

[5] Silva DJP. Gestão ambiental em uma indústria de produtos lácteos. Revista Leite e Derivados. 2006;94:52-63

[6] Vourch $\mathrm{M}$ et al. Treatment of dairy industry wastewater by reverse osmosis for reuse water. Dessalination. 2008;219:190-202

[7] Cavalcanti JEW d A. Manual de tratamento de efluentes industriais. 2nd ed. São Paulo: Engenho Editora Técnica; 2012

[8] Pires ECD, Del Nery MHRZ. Tratamento de águas residuárias industriais. In: Calijuri MdoC, Cunha DGF (coord), editors. Engenharia ambiental: conceitos, tecnologia e gestão. 1st ed. Rio de Janeiro: Elsevier; 2013

[9] Tchamango $\mathrm{S}$ et al. Treatment of dairy effluents by electrocoagulation using aluminium electrodes. Science of the Total Environment. 2010;408:947-952

[10] Lásló, et al. Effect of preozonation on the filterability of model dairy wastewater in nanofiltration. Desalination. 2009;240:170-177

[11] Federação Das Indústrias do Estado De Minas Gerais - FIEMG. Guia técnico ambiental da indústria de laticínios. 1st ed. Minas Gerais: FIEMG; 2014

[12] Schmitt DMF et al. Estudo da eficiência do composto ativo de Moringa Oleífera extraída com soluções salinas na tratabilidade de águas residuárias da indústria de laticínios. Revista Engevista. 2014;16:221-231 
[13] Constanzi RN. Tratamento de efluentes domésticos por sistemas integrados de lodos ativados e membranas de ultrafiltração visando o reuso de água [thesis]. São Paulo: Escola Politécnica de São Paulo; 2007

[14] Hespanhol I. Potencial de Reuso de Água no Brasil Agricultura, Indústria, Municípios, Recarga de Aquíferos. Revista Brasileira de Recursos Hídricos. 2002;7:75-95

[15] Árevalo J et al. Wastewater reuse after treatment by MBR. Microfiltration or ultrafiltration? Desalination Journal. 2012:299

[16] Andrade LH et al. Nanofiltration as a post treatment to membrane bioreactor effluent for dairy wastewater reuse. Procedia Engineering. 2012;4:1956-1960

[17] Andrade LH, Mendes FDdeS, Cerqueira N, Espíndola JCA, Amaral MCS. Distribuição de massa molar em um biorreator com membrana para tratamento de efluente de laticínios. Revista de Engenharia Sanitária e Ambiental. 2014;19

[18] Telles DD; Costa RHPG (coord), editors. Reúso da água: conceitos, teorias e práticas. 2nd ed. São Paulo: Blucher; 2010

[19] Mierzwa JC. O uso racional e o reúso como ferramentas para o gerenciamento de águas e efluentes na indústria - estudo de caso da Kodak Brasileira [thesis]. São Paulo: Universidade de São Paulo; 2002

[20] Federação Das Indústrias Do Estado Do Rio De Janeiro - FIRJAN. Manual de conservação e reúso da água na indústria. 1st ed. Rio de Janeiro: DIM; 2006

[21] Schneider RP, Tsutyia MT. Membranas Filtrantes para o tratamento de água, esgoto e água de reúso. 1st ed. São Paulo: ABES; 2001

[22] Habert AC, Borges CP, Nobrega R. Processos de separação por membranas. 1st ed. Rio de Janeiro: E-papers; 2006

[23] Mierzwa JC. Processos de separação por membranas: conceitos para uma aplicação eficiente [Internet]. 2007 [Updated: 2007]. Available from: http://www.cepema.usp.br/wpcontent/uploads/2011/06/IV-EPOA_-4.pdf> [Accessed: 15 março. 2015]

[24] Wagner J. Membrane Filtration Handbook: Practical tips and hints. 2nd ed. Osmonics; 2001

[25] Baker RW. Membrane Technology and Applications. 2nd ed. California: John Wiley \& Sons, Ltda; 2004

[26] Acero JL. Membrane filtration technologies applied to municipal secondary effluents for potential reuse. Journal of Hazardous Materials. 2010;177:390-398

[27] Lautenschlager RS, Filho SSF, Pereira O. Modelação matemática e otimização operacional de processos de membrana de ultrafiltração. Revista de Engenharia Sanitária e Ambiental. 2009;14:215-222

[28] Hasan A, Peluso CR, Hull TS, Fieschko J, Chatterjee SG. A surface-renewall model of cross-flow microfiltration. Brazilian Journal of Chemical Engineering. 2013;30:167-186 
[29] Giacobbo A, Rodrigues MAS, Bernardes AM, Ferreira JZ, Meneguzzi A. Microfiltração aplicada ao tratamento de efluentes de curtume. VII Simpósio Internacional de Qualidade Ambiental. Porto Alegre: Rio Grande do Sul; 2010

[30] Song L. Flux decline in crossflow microfiltration and ultrafiltration: Mechanisms and modeling of membrane fouling. Journal of Membrane Science. 1998;139:183-200

[31] Vidal CMS, Campos JR. Coagulação associada à microfiltração para o tratamento avançado de esgoto sanitário. Revista Ambiência. 2009;5:101-114

[32] Chmiel H, Mavrov V, Belières E. Reuse of vapour condensate from milk processing using nanofiltration. Filtration+Separation. 2000: 24-27

[33] Khider K, Akretche DE, Larbot A. Purification of water effluent from a milk factory by ultrafiltration using Algerian clay support. Dessalination. 2004;167:147-151

[34] Baldasso C. Concentração, purificação e fracionamento das proteínas do Soro Lácteo através da Tecnologia de Separação por Membranas [dissertation]. Porto Alegre: Programa de Pós-Graduação em Engenharia Química; 2008

[35] Luo J. Treatment of dairy effluent by shear-enhanced membrane filtration: The role of foulants. Separation and Purification Technology. 2012;96:194-203

[36] Brião VB, Tavares CRG. Ultrafiltração como processo de tratamento para o reúso de efluentes de laticínios. Revista de Engenharia Sanitária e Ambiental. 2007;12:134-138

[37] Schimitt DMF et al. Ultrafiltration combined with coagulation/flocculation/sedimentation using Moringa oleifera as coagulant to treat dairy industry wastewater. Water, Air, and Soil Pollution. 2013;224:1-10

[38] Kumar RV, Goswami L, Pakshirajan K, Pugazhenthi G. Dairy wastewater treatment using a novel low cost tubular ceramic membrane and membrane fouling mechanism using pore blocking models. Journal of Water Process Engineering. 2016;13:168-175

[39] Galvão DF. Pós-tratamento de efluentes por processos de separação por membranas e reúso de água em uma indústria de laticínios [dissertation]. Medianeira: Programa de Pós-Graduação em Tecnologias Ambientais; 2016. p. 117 
